\title{
CHAF1A Gene
}

National Cancer Institute

\section{Source}

National Cancer Institute. CHAF1A Gene. NCI Thesaurus. Code C106136.

This gene plays a role in both transcriptional regulation and nucleosome assembly. 